\title{
Anti-mycobacterial assessment and characterization of 5-O- caffeoylquinic acid methyl ester and rutin from Pavetta crassipes
}

\author{
Patricia O. Odumosu*, William John Lough, Davis Yakubu, Keith Thomas, Gemma Williamson, Nicolas Haroune \\ Sunderland School of Pharmacy, Faculty of Applied Sciences, University of Sunderland, SR1 3SD, U.K.
}

\begin{tabular}{|c|c|}
\hline ARTICLE INFO & ABSTRACT \\
\hline $\begin{array}{l}\text { Article history: } \\
\text { Received on: } 04 / 07 / 2016 \\
\text { Revised on: } 13 / 08 / 2016 \\
\text { Accepted on: } 10 / 09 / 2016 \\
\text { Available online: } 29 / 10 / 2016\end{array}$ & $\begin{array}{l}\text { Pavetta crassipes leaf (Fam. Rubiaceae) is used as part of a combination herbal remedy for the treatment of } \\
\text { tuberculosis (TB) and other respiratory infections in Nigerian ethno medicine. However, little scientific data is } \\
\text { available to support the use in ethnomedical therapy so the objective of the study was to assess the anti- } \\
\text { tubercular property and to identify the bioactive components. The dried powdered leaf was sequentially } \\
\text { extracted with solvents to obtain hexane, dichloromethane, methanol and water extracts. Following which, the }\end{array}$ \\
\hline $\begin{array}{l}\text { Key words: } \\
\text { Ethno medicine, M. aurum, } \\
\text { polyphenols, reversed phase } \\
\text { semi-preparative HPLC, LC- } \\
\text { MS, tuberculosis. }\end{array}$ & $\begin{array}{l}\text { species for activity. The methanol extract exhibited inhibitory activity at an MIC value of } 250 \mu \mathrm{g} / \mathrm{mL} \text { against M. } \\
\text { aurum and two known polyphenolic compounds were isolated as } 5 \text {-O-caffeoylquinic acid methyl ester and } \\
\text { quercetin-3-rutinoside (rutin). Reversed phase semi-preparative HPLC, mass spectrometry and } 1 \mathrm{H} \text { and } 13 \mathrm{C} \\
\text { NMR techniques were utilized in isolating and characterizing the two components. The assignments of the } \\
\text { structures were consistent with data from the literature. The study has shown that the methanol extract has some } \\
\text { activity and hyphenation of LC-MS can be used for the isolation of polyphenols from the methanol fraction } \\
\text { without a rigorous purification process. }\end{array}$ \\
\hline
\end{tabular}

\section{INTRODUCTION}

Pavetta crassipes K Schum (Rubiaceae) is a plant found in the West African sub - region with about 91 genera and 531 species (Gill, 1988). The leaves are used as food, as an antimalarial remedy, therapy for respiratory disorders, hypertension, gonorrhea, mental illness, and hookworm in ethno medicine (Hutchinson and Dalziel, 1954; Amos et al., 2003; Chabra et al., 1991). Anti-malarial, anti-inflammatory, muscle relaxant and hypotensive effects have been reported for the aqueous and ethanol extracts of the leaves (Amos et al., 1998a, b; Sanon et al., 2003). Although alkaloids and polyphenols have been implicated in the biological activities reported by other investigators, from

\footnotetext{
* Corresponding Author

Patricia O. Odumosu, Department of Pharmaceutical Chemistry, Faculty of Pharmaceutical Sciences, University of Jos, Jos. Nigeria Email: podumosu@ unijos.edu.ng
}

other species of Pavetta and other plant parts, there is no data on the structure elucidation of the bioactive constituents against tuberculosis based on literature accessed (Sanon et al., 2005; Weniger et al., 2004; Baldé et al., 1991a, b). This study describes the anti-mycobacterial activities, isolation and structural identification of two compounds, 5-O-caffeoyl quinic acid methyl ester and rutin using reversed phase semi-preparative HPLC, 1D and 2D NMR in addition to MS techniques.

\section{EXPERIMENTAL}

\section{Plant material}

The leaves of $P$. crassipes were collected from Jos, Plateau State, in the middle belt region of Nigeria, West Africa. The plant was identified by G.S Suberu and authenticated by Prof. O. Olorede, University of Abuja, Nigeria. The plant identity was further confirmed by Dr Martin Cheek of Royal Botanic Gardens, Kew, UK (Voucher specimen number: K000411874). 


\section{Extraction and isolation}

The leaves $(100 \mathrm{~g})$ were dried and sequentially extracted with hexane, dichloromethane, methanol and water at room temperature. The methanol extract ( $13 \%$ yield) was dissolved in methanol-water $(15: 85, \mathrm{v} / \mathrm{v})$ and filtered with a $0.2 \mu \mathrm{m}$ pore size syringe filter (PTFE ACRODISC FILTER). HPLC separation was initially performed on an analytical column (ACE 5 SIL C18 column, 250 x $4.6 \mathrm{~mm}$, HiChrom Ltd, UK) at $1 \mathrm{~mL} / \mathrm{min}$ using a 1 $\mathrm{mg} / \mathrm{mL}$ sample and scaled up to preparative levels using a semipreparative column (ACE 5 SIL C18, 250 x 10 mm, HiChrom Ltd, UK). The methanol extract $(10 \mathrm{mg} / \mathrm{ml})$ was eluted with methanolwater $(15: 85, \mathrm{v} / \mathrm{v})$ mobile phase at a flow rate of $5 \mathrm{ml} / \mathrm{min}$ with injection volume of $1000 \mu \mathrm{l}$ using the gradient profile as follows;

\begin{tabular}{cc}
\hline A-methanol (15\%) Time (mins) & B-water (85\%) \% B \\
\hline $0-5$ & $80-50$ \\
$5-16$ & 50 \\
$16-17$ & $50-80$ \\
$17-20$ & 80 \\
\hline
\end{tabular}

The eluents were collected in eight fractions and dried with fractions 5 and 7 yielding $6.1 \mathrm{mg}$ and $9.1 \mathrm{mg}$ respectively after 11 injections.

\section{Isolation and cultivation of M. aurum}

M. aurum NCTC 10438 was inoculated into glucose broth and incubated at $37^{\circ} \mathrm{C}$ for 72 hours. Working suspensions were prepared from dilutions of 72-hour cultures made by comparison to 0.5 McFarland turbidity standard.

\section{Determination of MIC by micro broth dilution assay}

A concentration range of $125-1000 \mu \mathrm{g} / \mathrm{mL}$ of the plant extracts was prepared directly on the multi-well plate for MIC determination. This was incubated at $37^{\circ} \mathrm{C}$ for 72 hours with a bacterial suspension of $M$. aurum prepared from a fresh colony maintained on glucose agar and adjusted to a turbidity equivalent to that of a $0.5 \mathrm{McF}$ arland tube. A dilution of 1 in 100 was made in broth and $100 \mu \mathrm{L}$ transferred to wells containing $100 \mu \mathrm{L}$ of extracts which had $2 \times$ the final concentration. After 3-5 days of incubation, $20 \mu \mathrm{L}$ of MTT [3(4, 5-dimethylthiazol-2-yl)-2, 5diphenyltetrazolium bromide] was added to each well and the plate was re- incubated for a few hours followed by visual reading. The method is based on the reduction of a colored indicator MTT which changes from yellow to purple. The color change indicates the growth of bacteria and MIC was defined as the lowest concentration of the extract that prevented the change in color.

\section{Chromatographic and spectroscopic procedures}

HPLC (analytical and semi-preparative) was performed on HP 1090 and Agilent 1200 series equipped with a UV photo diode array detector respectively. The instruments and data processing were controlled by the Chemstation software. Ace 5 C18 columns, $250 \times 4.6 \mathrm{~mm}$ and $250 \times 10 \mathrm{~mm}$ (HiChrom Ltd) were used for analytical and semi-preparative HPLC respectively. HPLC grade solvents were obtained from sigma Aldrich, UK. 1D
${ }^{1} \mathrm{H}$ and ${ }^{13} \mathrm{C}$, and 2D TOCSY, HSQC and HMBC spectra were recorded on a Bruker AVANCE $500 \mathrm{MHz}$ spectrometer fitted with a BBO probe equipped with a z-gradient coil. NMR experiments were carried out at $25^{\circ} \mathrm{C}$. Mass spectral data were obtained using Bruker Esquire 3000+ ion trap mass spectrometer while accurate mass measurements were recorded on a High Resolution-ESI Fourier Transform MS (Thermo 7T LTQ Ultra Hybrid Mass Spectrometer).

\section{RESULTS AND DISCUSSION}

\section{Biological testing}

The extracts of dried and powdered $P$. crassipes leaves were obtained from sequential extraction with hexane, dichloromethane, methanol and water. All the extracts were tested against $M$. aurum NCTC 10438, a preliminary model organism for investigating anti-tubercular compounds by an in vitro micro plate colorimetric assay method subsequent to testing against $M$. tuberculosis H37Rv, virulent strain of tuberculosis (Chung et al., 1995; Palomino et al., 2002). The tests were conducted to ascertain the biological activity against tuberculosis organisms based on ethno medical information. Initial screening studies with the methanol extract of $P$. crassipes showed inhibitory activity against $M$. aurum at a minimum inhibitory concentration of 250 $\mu \mathrm{g} / \mathrm{ml}$ using streptomycin as positive control. So attempts were made to separate and identify the constituents of the extract using LC, MS and NMR. In general, saprophytic non-pathogenic strains of mycobacteria are used in preliminary screening assays in order to obtain quick results and/or because of biosafety concerns in working with virulent $M$. tuberculosis. The non-pathogenic strains have advantages such as rapid growth and the use of Class 1 or 2 laboratory facilities which are readily available in most institutions (Franzblau et al., 1998; Newton et al., 2000). The methanol fraction showed inhibitory activity at $250 \mu \mathrm{g} / \mathrm{mL}$ against $M$. aurum and could be considered the most active fraction based on the results which led to further investigations on the fraction (Table 1). Chung et al., (1995) conducted a study in which they investigated uracil uptake in Mycobacterium aurum and $M$. tuberculosis H37Rv in the bid to develop a high-through put screen for detecting anti-TB compounds. Their observations of the relative susceptibilities to four first line anti-TB drugs showed that $M$. aurum had high predictive ability for high throughput anti-TB screening though H37Ra (ATCC 25177) avirulent strain of $M$. tuberculosis and M. bovis BCG (ATCC 35743) are reportedly closely related to $M$. tuberculosis virulent strain in terms of drug susceptibility profile and genetic composition. The results obtained using the micro dilution method exhibited higher MIC values compared to the disc assay method not reported here (Odumosu, 2012). However, it is possible that this might result in a few false leads as suggested with some of the values obtained (Table 1).

The advantage of subjecting the false positive extracts to further testing is that the probability of missing possible active fractions or compounds would be greatly reduced since all fractions were tested (Pauli et al., 2005). 
Table 1: M. aurum testing at test concentrations of $1000-125 \mu \mathrm{g} / \mathrm{mL}$ by micro plate agar dilution method.

\begin{tabular}{lll}
\hline CODE & EXTRACT SOURCE & MIC $(\boldsymbol{\mu g} / \mathbf{m L})$ \\
\hline PCH & P. crassipes hexane & $>1000$ \\
PCD & P. crassipes dichloromethane & $>1000$ \\
PCM & P. crassipes methanol & 250 \\
PCW & P. crassipes water & $>1000$ \\
STM & Streptomycin & 10 \\
AMP & Ampicillin & 100 \\
\hline
\end{tabular}

Table 2: Retention time $\left(\mathrm{t}_{\mathrm{R}}\right)$, UV $(\lambda \max )$ and MS data of Compounds PCM 5 and PCM 7 from P. crassipes methanol leaf extract.

\begin{tabular}{lcccc}
\hline Compound & $\mathbf{t}_{\mathbf{R}}-\mathbf{m i n}$ & $\mathbf{U V ~} \boldsymbol{\lambda} \mathbf{m a x}$ & \multicolumn{2}{c}{$\boldsymbol{m} / \boldsymbol{z}$ [identity] } \\
\cline { 3 - 5 } & & & molecular & formula \\
\cline { 3 - 5 } & & & & $\mathrm{C}_{17} \mathrm{H}_{19} \mathrm{O}_{9}$ \\
5- O-caffeoyl quinic acid methyl ester & 8.062 & $230,254,280$ & $367.10339[\mathrm{M}-\mathrm{H}]^{-}$ & $\mathrm{C}_{27} \mathrm{H}_{29} \mathrm{O}_{16}$ \\
Quercetin-3- rutinoside & 9.484 & $230,254,280$ & $609.14603[\mathrm{M}-\mathrm{H}]^{-}$ & \\
\hline
\end{tabular}

Table 3: ${ }^{1} \mathrm{H}$ and ${ }^{13} \mathrm{C}$ NMR spectral assignment of compound 5 from $P$. crassipes leaf isolate dissolved in $\mathrm{CD}_{3} \mathrm{OD}$.

\begin{tabular}{|c|c|c|c|c|}
\hline \multirow[t]{2}{*}{ Atom } & \multicolumn{2}{|c|}{5 - Me 5-CQA } & \multirow[b]{2}{*}{${ }^{13} \mathrm{C}$ HSQC } & \multirow[b]{2}{*}{${ }^{13} \mathrm{C}$ HMBC } \\
\hline & ${ }^{13} \mathrm{C}$ & ${ }^{1} \mathbf{H}$ & & \\
\hline 1 & 72.14 & - & & \\
\hline 2 & & $2.04-2.05(\mathrm{~m})$ & $\sim 36.9$ & \\
\hline 3 & & $4.16(\mathrm{~m})$ & $\sim 69$ & \\
\hline 4 & & $3.72(\mathrm{~m})$ & $\sim 71.7$ & \\
\hline 5 & & $5.29(\mathrm{~m})$ & $\sim 71$ & \\
\hline 6 & & $2.22(\mathrm{~m})$ & $\sim 37$ & \\
\hline $\mathrm{COO}-$ & 175.43 & & & \\
\hline $\mathrm{OCH}_{3}$ & 52.96 & $3.76(\mathrm{~s})$ & & \\
\hline $1^{\prime}$ & 122.98 & $6.96(\mathrm{dd}, 2.06 \mathrm{~Hz}, 8.25 \mathrm{~Hz})$ & & \\
\hline $2^{\prime}$ & 116.54 & $6.79(\mathrm{~d}, 8.25 \mathrm{~Hz})$ & & \\
\hline $3^{\prime}$ & 146.91 & - & & \\
\hline $4^{\prime}$ & & - & & $\sim 149$ \\
\hline $5^{\prime}$ & 115.09 & $7.06(\mathrm{~d}, 2.06 \mathrm{~Hz})$ & & \\
\hline $6^{\prime}$ & 127.61 & - & & \\
\hline $7^{\prime}$ & 147.22 & $7.53(\mathrm{~d}, 15.81 \mathrm{~Hz})$ & & \\
\hline $8^{\prime}$ & 115.01 & $6.22(\mathrm{~d}, 15.81 \mathrm{~Hz})$ & & \\
\hline $9^{\prime}$ & 168.27 & - & & \\
\hline
\end{tabular}

$\sim$ estimated chemical shift values in ppm from HSQC and HMBC spectra.

Recent reports on the anti-tubercular screening of $P$. crassipes against Bacille Calmette Guerin (BCG) and $M$. tuberculosis H37Rv strains showed variable MIC values but it was considered worthy of further study (Ibekwe et al., 2014). There are also reported anti-inflammatory and muscle relaxant effects of the aqueous extract of $P$. crassipes leaves which supports the 'herbal shotgun' principle where components play different functions in achieving therapy (Amos et al., 1998a).

\section{Isolation and Identification}

The test of the crude methanol extract with $\mathrm{FeCl}_{3}$ solution and $\mathrm{NaOH}$ gave positive results suggesting that tannins and flavonoids were present (Evans, 2009). Reversed phase semipreparative LC analysis of the methanol fraction resulted in eight fractions from which fractions 5 and 7 yielded $6.1 \mathrm{mg}$ and $9.1 \mathrm{mg}$ respectively after 11 injections (Figure 1). The two fractions were found to be of high enough purity (approximately 85\%) for analysis by NMR and mass spectrometry measurements. The same method was transferred to LC-MS in an attempt to carry out the isolation and characterization without the tedious procedures involved in preparative LC. The two fractions earlier obtained in a fairly pure state gave molecular weights of 369 (PCM 5) and 611 (PCM 7) and the accurate mass was confirmed by accurate mass and NMR.
The results obtained by mass spectrometry are presented in Table 2 while assignments of the NMR signals are presented in Tables 3 and 4 respectively.

The structures of the compounds, 5-caffeoyl quinic acid methyl ester (PCM 5) and quercetin-3-rutinoside (PCM 7) were confirmed by comparison of $1 \mathrm{H}$ and ${ }^{13} \mathrm{C}$ NMR data of the isolated compound to a standard sample of rutin (Sigma-Aldrich, S2424, Lot \# 129K2568V) and with literature values for 5-O-caffeoyl quinic acid methyl ester (Weniger et al., 2004; Baldé et al., 1991a, b). Compound 5 (Me 5-CQA) has a molecular formula $\mathrm{C}_{17} \mathrm{H}_{19} \mathrm{O}_{9}$ established by HR-ESI-MS (m/z: $367.10[\mathrm{M}-\mathrm{H}]^{-}$, calculated as 367.10, $\delta-0.18 \mathrm{ppm}$ (Figure 3, Table 2). Comparison of the ${ }^{1} \mathrm{H}$ and ${ }^{13} \mathrm{C}$ NMR data of Me 5-CQA (Table 3) with literature values showed similar signals (Chan et al., 2009; Clifford et al., 2003). Compound 7 (rutin) was compared to NMR data of an authentic sample and both compounds showed similar signals (Table 4). The molecular formula was established by HR-ESI-MS as $\mathrm{C}_{27} \mathrm{H}_{29} \mathrm{O}_{16}$ $\left(\mathrm{m} / \mathrm{z}: 609.14603[\mathrm{M}-\mathrm{H}]{ }^{-}\right.$, calculated as 609.14, $\delta-0.13 \mathrm{ppm}$ (Figure 4, Table 2). The ${ }^{1} \mathrm{H}$ NMR data showed proton peaks at $\delta 3.00$ - $\delta 4.00$ with an integral of $\sim 9$ which were suggestive of carbon atoms bearing hydroxyl groups. The proton signals at $\delta 5.10$ and at $\delta 3.52$ show correlation in the TOCSY spectrum which is consistent with an anomeric proton coupled to the ring system of a sugar molecule. 
Table 4: ${ }^{1} \mathrm{H}$ and ${ }^{13} \mathrm{C}$ NMR spectral assignment of compound 7 from P. crassipes methanol leaf isolate dissolved in $\mathrm{CD}_{3} \mathrm{OD}$.

\begin{tabular}{|c|c|c|c|c|}
\hline Atom & \multicolumn{2}{|l|}{ 7- Rutin } & \multicolumn{2}{|c|}{ Rutin reference standard } \\
\hline & ${ }^{13} \mathrm{C}$ & ${ }^{1} \mathrm{H}$ & ${ }^{13} \mathrm{C}$ & ${ }^{1} \mathrm{H}$ \\
\hline 1 & 179.38 & - & 179.41 & - \\
\hline 2 & 135.6 & - & 135.64 & - \\
\hline 3 & 159.29 & - & 159.33 & - \\
\hline 4 & 158.56 & - & 158.50 & - \\
\hline 5 & 94.95 & $6.39(\mathrm{~d}, 1.83 \mathrm{~Hz})$ & 94.87 & $6.42(\mathrm{~d}, 2.07 \mathrm{~Hz})$ \\
\hline 6 & 166.48 & - & 165.98 & - \\
\hline 7 & 100.09 & $6.20(\mathrm{~d}, 1.83 \mathrm{~Hz})$ & 99.95 & $6.24(\mathrm{~d}, 2.07 \mathrm{~Hz})$ \\
\hline 8 & 162.98 & - & 162.96 & - \\
\hline 9 & 105.51 & - & 105.65 & - \\
\hline 10 & 123.54 & - & 123.57 & - \\
\hline 11 & 123.12 & $7.62(\mathrm{dd}, 1.83 \mathrm{~Hz}, 8.25 \mathrm{~Hz})$ & 123.15 & $7.64(\mathrm{dd}, 2.17,8.48 \mathrm{~Hz})$ \\
\hline 12 & 116.06 & $6.87(\mathrm{~d}, 8.48 \mathrm{~Hz})$ & 116.07 & $6.92(\mathrm{~d}, 8.48 \mathrm{~Hz})$ \\
\hline 13 & 145.86 & - & 145.82 & - \\
\hline 14 & 149.84 & - & 149.78 & - \\
\hline 15 & 117.66 & $7.66(\mathrm{~d}, 1.83 \mathrm{~Hz})$ & 117.71 & $7.69(\mathrm{~d}, 2.17 \mathrm{~Hz})$ \\
\hline $1^{\prime}$ & 104.75 & $5.10(\mathrm{~d}, 7.56 \mathrm{~Hz})$ & 104.74 & $5.15(\mathrm{~d}, 7.44 \mathrm{~Hz})$ \\
\hline $2^{\prime}$ & 78.20 & $3.40(\mathrm{~m})$ & 78.20 & $3.40(\mathrm{~m})$ \\
\hline $3^{\prime}$ & 75.73 & $3.46(\mathrm{~m})$ & 75.73 & $3.47(\mathrm{~m})$ \\
\hline $4^{\prime}$ & 69.71 & $3.44(\mathrm{~m})$ & 69.70 & $3.45(\mathrm{~m})$ \\
\hline $5^{\prime}$ & 73.93 & $3.27(\mathrm{~m})$ & 73.95 & $3.27(\mathrm{~m})$ \\
\hline $6^{\prime}$ & 68.55 & $3.36(\mathrm{~m}), 3.81(\mathrm{dd}, 1.15,11 \mathrm{~Hz})$ & 68.57 & $3.35,3.82(\mathrm{~d}, 10.27 \mathrm{~Hz})$ \\
\hline $7^{\prime}$ & 102.43 & $4.51(\mathrm{~s})$ & 102.41 & $4.55(\mathrm{~d}, 1.41 \mathrm{~Hz})$ \\
\hline $8^{\prime}$ & 77.23 & $3.32(\mathrm{~m})$ & 77.23 & $3.32(\mathrm{~m})$ \\
\hline $9^{\prime}$ & 72.24 & $3.52(\mathrm{dd}, 3.44,9.39 \mathrm{~Hz})$ & 72.26 & $3.53(\mathrm{dd}, 3.49,9.42 \mathrm{~Hz})$ \\
\hline $10^{\prime}$ & 71.4 & $3.25(\mathrm{~m})$ & 71.41 & $3.26(\mathrm{~m})$ \\
\hline $11^{\prime}$ & 72.11 & $3.62(\mathrm{~m})$ & 72.10 & $3.66(\mathrm{dd}, 1.60 \mathrm{~Hz})$ \\
\hline $12^{\prime}$ & 17.88 & $1.12(\mathrm{~d}, 6.19 \mathrm{~Hz})$ & 17.87 & $1.16(\mathrm{~d}, 6.22 \mathrm{~Hz})$ \\
\hline
\end{tabular}

Values of ${ }^{1} \mathrm{H}$ and ${ }^{13} \mathrm{C}$ chemical shifts are in ppm $(\delta)$, and those of coupling constants, $\mathrm{J}$ in $\mathrm{Hz}$

a)

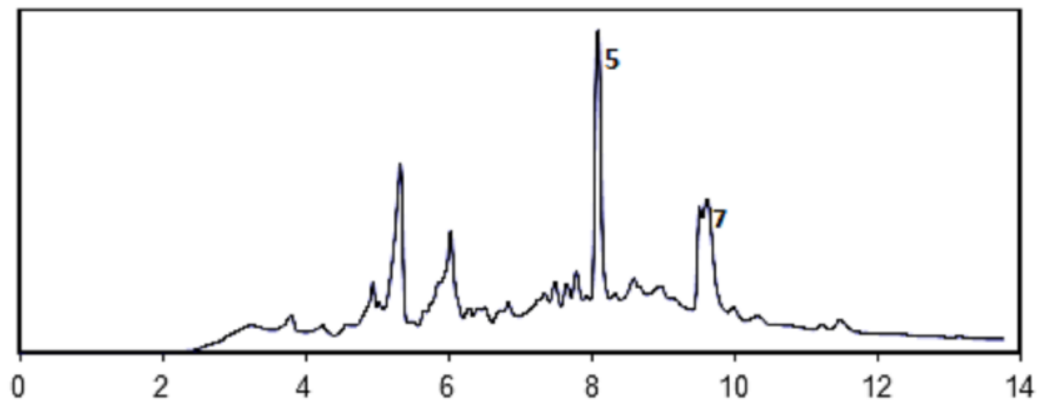

Retention time (min)

b)

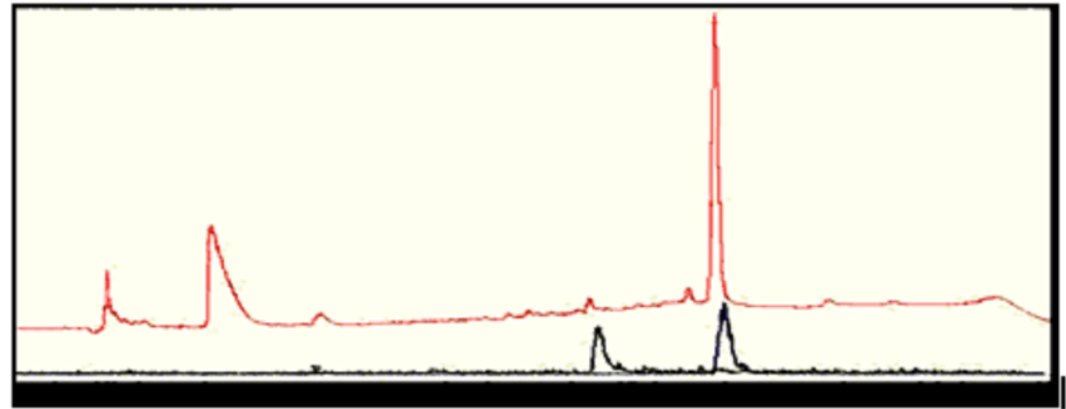

Fig. 1: a) HPLC/UV chromatogram of Pavetta crassipes methanol extract on ACE C18 column at $230 \mathrm{~nm}(250 \times 10$ $\mathrm{mm}, 5 \mu \mathrm{m}$ ). b) LC-MS UV trace at $225 \mathrm{~nm}$ (top trace), first peak is the extract ion chromatogram for 369 ion (PCM 5) while second peak is extract ion chromatogram for 611 ion (PCM 7). Data was acquired in positive mode. 
a)

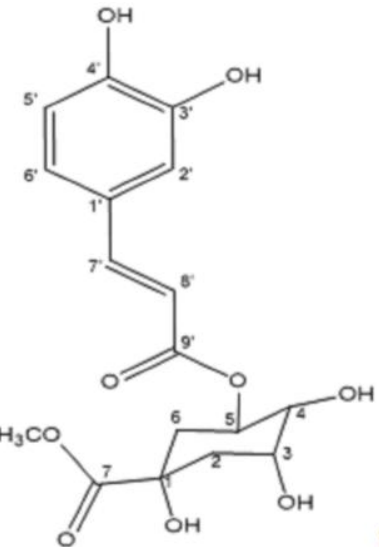

b)

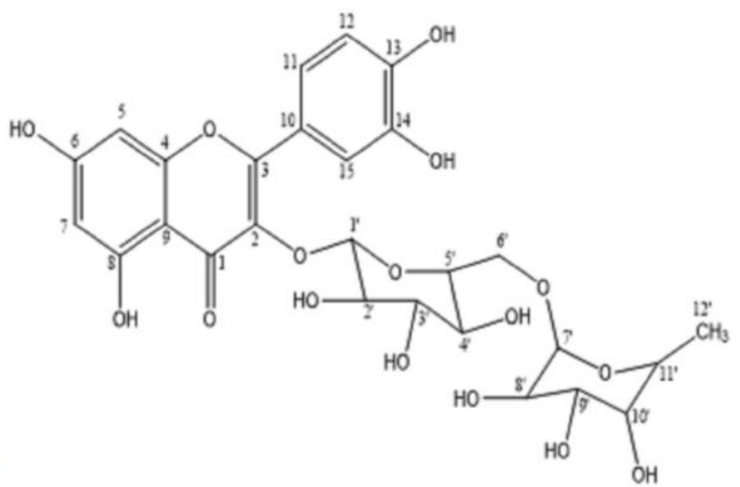

Fig. 2: Structures of 5-O-caffeoyl quinic acid methyl ester (a) and quercetin-3-rutinoside (rutin) (b).

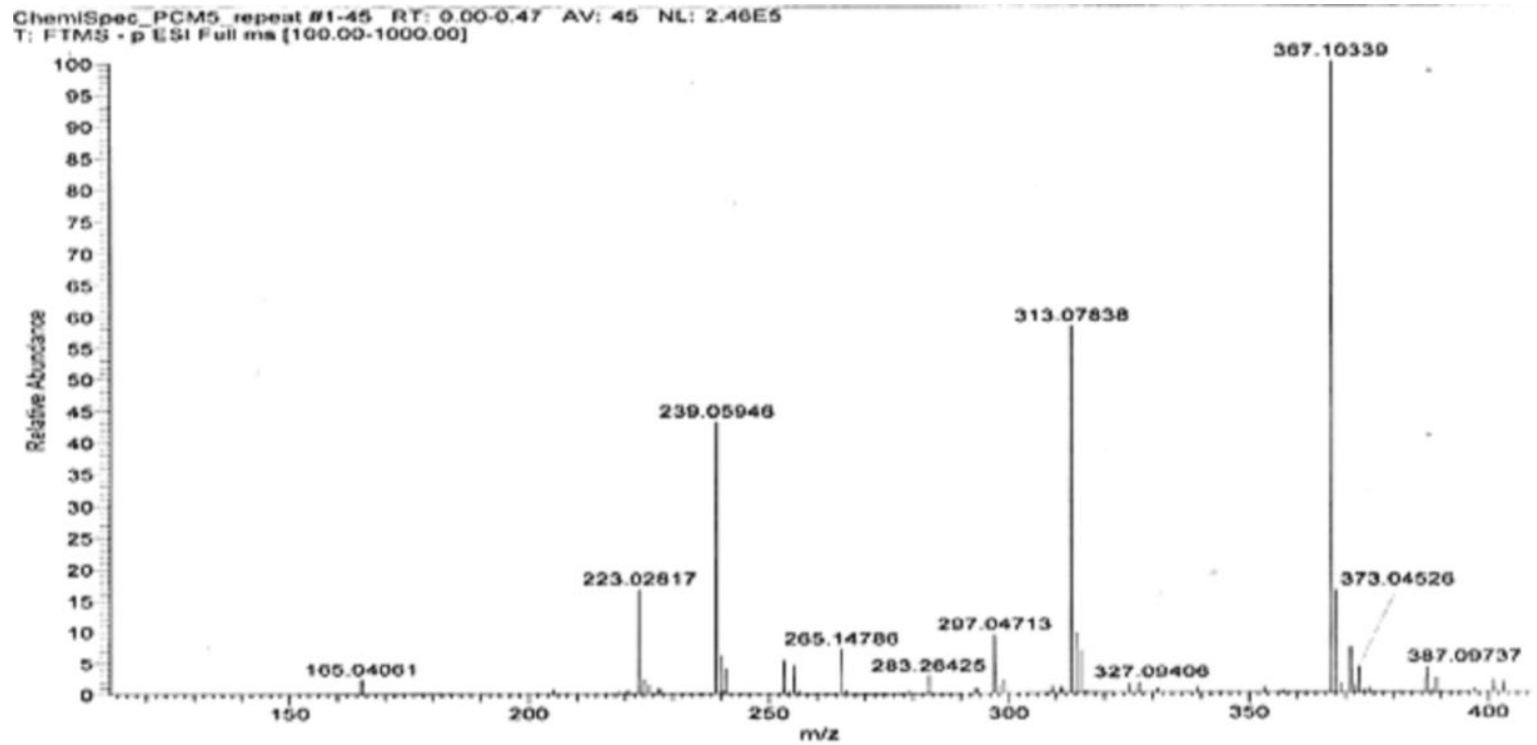

Fig. 3: Accurate mass spectrum of PCM 5 from P. crassipes leaf by ESI-MS (negative ion mode).

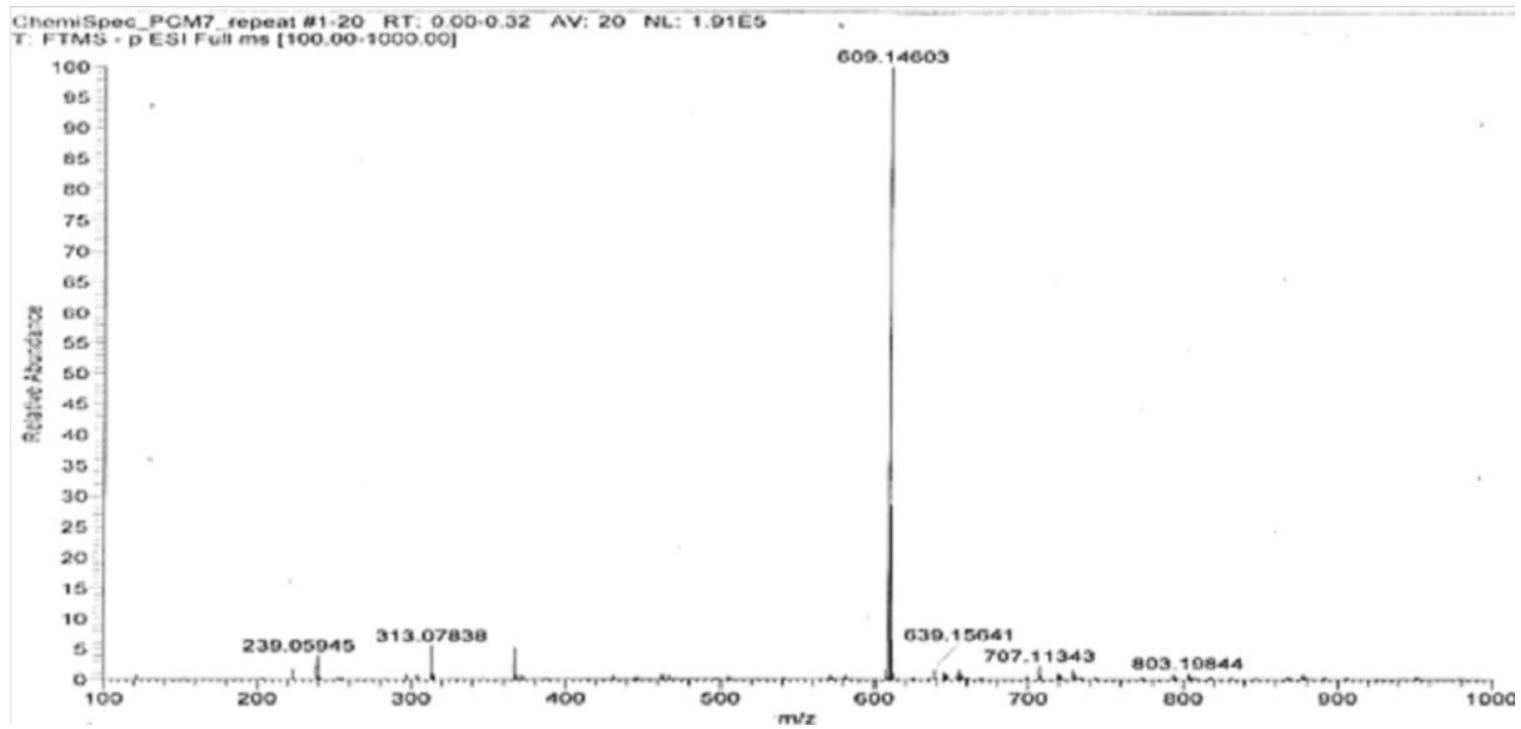

Fig. 4: Accurate mass measurement for PCM 7 from P. crassipes leaf by ESI- MS (negative ion mode). 
The elucidation of the structure was completed with the aid of HSQC and HMBC spectra. From the report of a review on plant-derived anti-mycobacterial natural products, bioactivity spans a wide range of phytochemicals such as lipids/fatty acids and simple aromatics, phenolics and acetogenic quinones, peptides, alkaloids, terpenes (monoterpenoids, diterpenes, sesquiterpenes, sesterterpenes) and steroids. Highly active compounds from these plants included; the lactone - containing tubelactomicin A, phenolics drummondins and ferulenol, xanthone, brasiliquinones $\mathrm{A}$ and $\mathrm{B}$, the alkaloids celastramycin $\mathrm{A}$, sampagine and the manzamines and steroids fusidic acid, saringosterol and ergosterol-5,8-endoperoxide which all exhibited antimycobacterial activity with MIC values $\leq 4 \mu \mathrm{g} / \mathrm{mL}$ (Copp, 2003).

These compounds show the chemical diversity and complexity displayed by plants compared to first-line and second line drugs such as rifampicin or amikacin used in therapy. Caffeoylquinic acid derivatives have been investigated and shown to have properties such as peroxynitrite-scavenging, hepatoprotective, anti-viral, anti-obese, and antidiabetic activities (Park, 2010). From this study, P. crassipes leaf extracts were not as active against the saprophytic TB organism used when compared to the reference antibiotics however, the inclusion in the herbal preparation could be justified by the principle of synergy where an extract is added to enhance the activity of the actives, such as stabilizing the actives through anti-oxidant action or enhancing bioavailability rather than anti-bacterial action (Williamson, 2001; Olthof et al., 2003). Further studies could be conducted to find out if the plant extracts have efflux properties or synergistic properties with the other components of the herbal preparation. In summary, $M$. aurum was easy to grow on glucose agar and useful for initial screening studies as well as for monitoring fractions during isolation of bioactive components. The compounds, 5-caffeoyl quinic acid methyl ester and rutin isolated from the leaf of Pavetta crassipes Fam. Rubiaceae using reversed phase semi- preparative LC have been reported to have other useful activities such as antioxidant properties. The inclusion of Pavetta leaves in herbal remedy used in treatment of respiratory infections possibly serves to enhance the activity of other plant component. The identification of compounds by their 1D/2D NMR \& mass spectrum was achieved without any need for further purification.

\section{ACKNOWLEDGMENTS}

Authors are Thankful to Dr. Jackie Mosely of Durham University, U.K. for accurate mass measurement.

Sources of Funding: P. Odumosu thanks the University of Sunderland, U.K for a part-funded $\mathrm{PhD}$ studentship.

Conflict of Interest: Authors' declare no conflict of interest.

\section{REFERENCES}

Amos S, Akah PA, Enwerem NM, Ogundaini A, Wambebe C, Hussaini IM, Gamaniel KS. Hypotensive activity of the ethanol extract of Pavetta crassipes leaves. Biol Pharm Bull, 2003; 26 (12):1674 -1680.
Amos S, Gamaniel K, Akah P, Wambebe C, Okwuasaba FK. Anti-inflammatory and muscle relaxant effects of the aqueous extract of Pavetta crassipes leaves. Fitoterapia, 1998a; 69 (5): 425 - 429.

Amos S, Okwuasaba FK, Gamaniel K, Akah P, Wambebe C. Inhibitory effects of the aqueous extracts of Pavetta crassipes leaves on gastrointestinal and uterine smooth muscle preparations isolated from rabbits, guinea pigs and rats. J Ethnopharmacol, 1998b; 61: 209-213.

Baldé A M, Pieters LA, Gergely A, Kolodziej H, Berghe DAV, Claeys M, Vlietinck, AJ. A-type proanthocyanidins from stem-bark of Pavetta owariensis. Phytochem, 1991; 30 (1): 337-342.

Baldé AM, Pieters TLA, Wray V, Kolodziej SH, Vanden Berghe SDA, Claeys M, Vlietinck AJ. Dimeric and trimeric proanthocyanidins possessing a doubly linked structure from Pavetta owariensis. Phytochem, 1991; 30 (12): 4129- 4135.

Chabra SC, Mahunna RL, Mshiu EN. Plants used in Traditional Medicine in Eastern Tanzania V. Angiosperms (Passifloraceae to Sapindaceae). J Ethnopharmacol, 1991; 33 (1-2): 143-157.

Chan EWC, Lim YY, Ling SK, Tan SP, Lim KK, Khoo MGH. Caffeoylquinic acids from leaves of Etlingera species (Zingiberaceae). Food Sci and Tech, 2009; 42: 1026 -1030.

Chung GAC, Akhtar Z, Jackson S, Duncan K. High-throughput screen for detecting antimycobacterial agents. Antimicrob Agents Chemother, 1995; 39: 2235-2238.

Clifford MN, Johnston KL, Knight S, Kuhnert N. Hierarchical scheme for LC-MS ${ }^{\mathrm{n}}$ identification of chlorogenic acids. J Agric Food Chem, 2003; 51: 2900-2911.

Copp BR. Antimycobacterial natural products. Nat Prods Rep, 2003; 20: $535-557$.

Evans WC. 2009. Phenols and phenolic glycosides. In: Trease and Evans Pharmacognosy $16^{\text {th }}$ ed. Saunders Elsevier Ltd 225- 252.

Franzblau SG, Witzig, RS, Mclaughlin, JC, Torres P, Madico G, Hernandez A, Degnan MT, Cook MB., Quenzer VK, Ferguson RM, Gilman RH. Rapid, low technology MIC determination with clinical Mycobacterium tuberculosis isolates by using the microplate alamar blue assay. J of Clin Microbiol, 1998; 36: 362-366.

Gill LS. 1998. Taxonomy of flowering plants. Africana FEP Publishers: Onitsha, Nigeria;

Hutchinson J, Dalziel JM. 1954. Flora of West Tropical Africa, Vol 1. Crown Agents for Overseas Government and Administrations: London.

Ibekwe NN, Nvau JB, Oladosu PO, Usman AM, Ibrahim K, Boshoff HI, Dowd CS, Orisadipe, AT, Aiyelaagbe O, Adesomoju AA, Barry, CE III, Okogun JI and in collaboration with 73 Visited Herbalists. Some Nigerian anti-tuberculosis ethnomedicines: A preliminary efficacy assessment. J Ethnopharmacol, 2014; 155(1): 524-532.

Newton SM, Lau C, Wright $\mathrm{CW}$. A review of antimycobacterial natural products. Phytother Res, 2000; 14: 302-322.

Odumosu PO. 2012. Evaluation of the plant extracts of an antitubercular herbal remedy. Doctoral thesis. University of Sunderland, UK. [Online] Available at: http://ethos.bl.uk/OrderDetails.do?uin=uk.bl.ethos.569064 [Accessed 12 August 2016].

Olthof MR, Hollman PCH, Buijsman MNCP, van Amelsvoort JMM, Katan MB. Chlorogenic acid, quercetin-3-rutinoside and black tea phenols are extensively metabolized in humans. J Nutr, 2003; 133: 18061814.

Palomino JC, Martin A, Camacho M, Guerra H, Swings J, Portaels F. Resazurin microtiter assay plate: simple and inexpensive method for detection of drug resistance in Mycobacterium tuberculosis. Antimicrob Agents and Chemother, 2002; 46: 2720-2722.

Park H-J. Chemistry and pharmacological action of caffeoylquinic acid derivatives and pharmaceutical utilization of Chwinamul (Korean mountainous vegetable). Arch of Pharmacol Res, 2010; 33 (11): 1703-1720.

Pauli GF, Case RJ, Inui $\mathrm{T}$, Wang $\mathrm{Y}$, Cho $\mathrm{S}$, Fischer $\mathrm{NH}$, Franzblau SG. New perspectives on natural products in TB drug research. Life Sci, 2005; 78: 485 - 494.

Sanon S, Azas N, Gasquet E, Ollivier V, Barro N, CuzinOuattara N, Mahiou V, Traore SA, Esposito F, Balansard G, Timon- 
David P. Antiplasmodial activity of alkaloid extracts from Pavetta crassipes (K. Schum) and Acanthospermum hispidum (DC), two plants used in traditional medicine in Burkina Faso. Parasit Res, 2003; 90: 314 317.

Sanon S, Mahiou V, Nebie I, Azas N, Ollivier E, Timon-David P, Balansard G, Traore A. In-vitro antimalarial properties of two plants used by traditional herbal practitioners of Burkina Faso: Pavetta crassipes and Mithragyna inermis [MIM-SS-81397]. Parallel sessions-abstracts of presentations. Acta Trop, 2005; 95 (1): 1-506.

Weniger B, Lagnika L, Vonthron-Sénécheau C, Adjobimey T, Gbenoud J, Moudachirou M, Brun R, Anton R, Sanni A. Evaluation of ethnobotanically selected Benin medicinal plants for their in-vitro antiplasmodial activity. J Ethnopharmacol, 2004; 90: 279 - 284.
Williamson EM. Synergy and other interactions in phytomedicines. Phytomed, 2001; 8 (5): 401- 409.

\section{How to cite this article:}

Odumosu PO, Lough WJ, Yakubu S, Thomas K, Williamson G, Haroune N. Anti-mycobacterial assessment and characterization of 5-O-caffeoylquinic acid methyl ester and rutin from Pavetta crassipes. J App Pharm Sci, 2016; 6 (10): 001-007. 